\section{RMD Open}

Rheumatic \&

Musculoskeletal Diseases

\title{
Measurement properties of the minimal disease activity criteria for psoriatic arthritis
}

Laura C Coates, ${ }^{1}$ Vibeke Strand, ${ }^{2,3}$ Hilary Wilson, ${ }^{4}$ Dennis Revicki, ${ }^{5}$ Brad Stolshek, ${ }^{6}$ Ahmed Samad, ${ }^{7}$ James B Chung, ${ }^{8}$ Dafna Gladman, ${ }^{\circ}{ }^{9}$ Philip J Mease ${ }^{\bullet 10}$

To cite: Coates LC, Strand V, Wilson $\mathrm{H}$, et al. Measurement properties of the minimal disease activity criteria for psoriatic arthritis. RMD Open 2019;5:e001002. doi:10.1136/ rmdopen-2019-001002

- Additional material is published online only. To view please visit the journal online (http://dx.doi.org/10.1136/ rmdopen-2019-001002).

Received 8 May 2019 Revised 24 July 2019 Accepted 11 August 2019
Check for updates

(C) Author(s) (or their employer(s)) 2019. Re-use permitted under CC BY-NC. No commercial re-use. See rights and permissions. Published by BMJ.

For numbered affiliations see end of article.

Correspondence to Dr Hilary Wilson; hilary.wilson@boehringeringelheim.com

\section{ABSTRACT}

Objective To comprehensively assess evidence on the measurement properties of the minimal disease activity (MDA) criteria, a composite measure of the state of disease activity in psoriatic arthritis (PsA).

Methods A targeted literature review was conducted to identify studies that informed the validity and/or ability of the MDA to detect change among patients known to have experienced a change in clinical status. The search was conducted using MEDLINE and Embase databases (published as of October 2017). Pertinent articles provided by investigators and identified from select conference proceedings were also evaluated.

Results A total of 20 publications met the inclusion criteria. The MDA criteria were consistently associated with other indicators of disease activity/severity. The ability of the MDA criteria to detect change was supported in randomised controlled trials $(n=10)$, with a greater percentage of patients randomised to active treatments achieving MDA relative to patients in comparator arms. Long-term observational studies $(\mathrm{n}=2)$ provided additional support for the ability of the MDA to detect within-subject change in the real-world settings.

Conclusion Evidence supports the MDA as a valid measure of disease activity in PsA that can detect between-group and within-subject change. The MDA is a comprehensive measure and clinically meaningful endpoint to assess the impact of interventions on PsA disease activity.

\section{INTRODUCTION}

Psoriatic arthritis (PsA) is a chronic immune-mediated inflammatory musculoskeletal disease. ${ }^{1}$ As an immune-mediated disease with heterogeneous manifestations, it typically presents with skin and musculoskeletal symptoms, including skin and nail psoriasis, peripheral arthritis, enthesitis, dactylitis and spondylitis. ${ }^{23}$ PsA may result in permanent joint damage leading to reduced health-related quality of life (HRQoL) and physical function. ${ }^{2-4}$ Associated comorbidities include cardiovascular disease, ${ }^{135}$ metabolic syndrome, ${ }^{35}$ obesity, ${ }^{356}$ depression, ${ }^{135}$

\section{Key messages}

What is already known about this subject?

- Psoriatic arthritis (PsA) is an immune-mediated disease with heterogeneous manifestations. Currently, available measures do not capture all relevant aspects of the PsA disease activity, thus emphasising the need for a disease assessment tool that is targeted and comprehensive, which can assess multiple domains of the disease.

What does this study add?

- This is a targeted literature review of the available evidence that supports utility, validity and relevance of the minimal disease activity (MDA) as a measure of disease activity in PSA.

How might this impact on clinical practice?

- This targeted literature review provides supportive evidence for MDA criteria as a targeted, practical and easy to interpret measure that can be used in both clinical practice and randomised controlled trials to assess disease activity in PsA.

anxiety, ${ }^{135}$ and may include conditions, such as inflammatory bowel disease ${ }^{35}$ and uveitis. ${ }^{57}$ Prevalence among the general population has been reported to range from 1 to 420 cases per 100000 globally; and 250 cases per 100000 in the USA. ${ }^{8}$ Among patients with psoriasis, the prevalence varies from $6 \%$ to $41 \%$ depending on study methodology ${ }^{3}$ and the annual incidence has been reported to be approximately $3 \%$ in patients followed prospectively. ${ }^{9}$ Diagnosis and assessment of PsA is complex as a result of heterogeneity in disease presentation and the presentation of symptoms that evolve over the course of the disease. ${ }^{10} 11$ Patients can experience periods of disease flares, minimal disease activity (MDA) and remission. ${ }^{12}$

The ultimate treatment goal for PsA is clinical remission or inactive disease. ${ }^{13} 14$ Since, for many patients, complete remission may 


\begin{tabular}{lllll} 
Author (year) & Study description & Sample size & MDA subgroup & (SD) \\
\hline $\begin{array}{l}\text { Coates and Helliwell } \\
(2010)^{22}\end{array}$ & $\begin{array}{l}\text { Post hoc analysis of two } \\
\text { RCTs to validate the MDA } \\
\text { criteria }\end{array}$ & 157 & MDA $(\mathrm{n}=63)$ & $\begin{array}{l}\text { Median, } 0.4 \mathrm{mg} / \mathrm{dL} \\
(0.4-0.6)\end{array}$ \\
& & & Non-MDA $(\mathrm{n}=94)$ & $\begin{array}{l}\text { Median, } 0.5 \mathrm{mg} / \mathrm{dL} \\
(0.4-1.3)\end{array}$ \\
& & & P value & 0.019 \\
Queiro et al $(2017)^{25}$ & $\begin{array}{l}\text { Cross-sectional } \\
\text { observational study }\end{array}$ & 277 & MDA $(\mathrm{n}=133)$ & $\begin{array}{l}\text { Mean, } 2.8 \mathrm{mg} / \mathrm{L}(3.9) \\
\end{array}$ \\
& & Non-MDA $(\mathrm{n}=144)$ & $\begin{array}{l}\text { Mean, } 4.7 \mathrm{mg} / \mathrm{L}(8.2) \\
\text { P value }\end{array}$ & $<0.05$
\end{tabular}

CRP, C reactive protein; MDA, minimal disease activity; Non-MDA, patients not achieving MDA; RCT, randomised controlled trial.

be difficult to attain, MDA, low or very low disease activity (VLDA) have been proposed as alternative goals. Given the multiple domains of PsA, a composite endpoint that captures all relevant aspects of the disease is critical to the overall interpretation of research study results and patient management. The PsA core domain set recommended by the Group for Research and Assessment of Psoriasis and Psoriatic Arthritis (GRAPPA)/Outcome Measures in Rheumatology (OMERACT) for randomised controlled trials (RCTs) and long-term observational studies includes musculoskeletal disease activity, skin disease activity, fatigue, pain, patient global assessment (PtGA), physical function, HRQoL and systemic inflammation (defined by acute phase reactants) as key domains that are important to both patients and physicians. ${ }^{15}$ The most common PsA endpoint for Food and Drug Administration approval of treatments is the American College of Rheumatology (ACR) response criteria, ${ }^{16}$ which were developed as an endpoint for rheumatoid arthritis RCTs. The ACR response criteria do not capture the distinct features of PsA, such as enthesitis, dactylitis, axial disease or skin manifestations, thus, additional instruments to assess these manifestations are included in RCTs, such as the Psoriasis Area Severity Index (PASI) and assessments for the presence of dactylitis and enthesopathy. ${ }^{17-19}$ Several composite disease measures have been proposed, including Disease Activity in Psoriatic Arthritis (DAPSA; focuses solely on arthritis), Composite Psoriatic Disease Activity Index (CPDAI), Psoriatic Arthritis Disease Activity Score (PASDAS), Psoriatic Arthritis Response Criteria (focuses solely on arthritis) and GRAPPA Composite Exercise Index. ${ }^{20}$ These measures are all continuous and remission is generally defined as a score below a cut-off value.

Recognising the need for a tool to better capture heterogeneous disease activity among PsA patients that equates to a clinically meaningful indicator of disease status, Coates et al developed a PsA-specific, composite measure of disease state, the MDA criteria. ${ }^{21} 22$ The MDA criteria were developed consistent with OMERACT recommendations. In contrast to continuous measures, the MDA serves as an indicator of the current state of
PsA disease. ${ }^{20}$ Patients achieve MDA if they meet five of seven criteria: tender joint count $\leq 1$; swollen joint count $\leq 1$; PASI $\leq 1$ or body surface area (BSA) $\leq 3$; patient pain Visual Analogue Scale (VAS) $\leq 15$; PtGA $\leq 20$; Health Assessment Questionnaire (HAQ) $\leq 0.5$ and tender entheseal points $\leq 1$ (21). MDA response rates have been assessed in longitudinal observational studies (LOSs) and RCTs. ${ }^{20}$ Individual components of the MDA criteria are well established. Of the seven individual components, five components are included in the ACR response criteria and the remaining two components (ie, PASI $\leq 1$ or BSA $\leq 3$ and tender entheseal points $\leq 1$ ) have been used in RCTs to assess the efficacy of PsA treatments. The MDA is gaining acceptance as a meaningful composite index that can be used to monitor disease activity across all PsA clinical pathologies ${ }^{23}$ and has been proposed as a comprehensive measure for treat-to-target (T2T) approach in PsA. ${ }^{13}$ Recently, VLDA has become a clinically relevant benchmark for disease remission and has been defined as meeting seven of the seven MDA criteria. ${ }^{23}$

The objectives of this targeted literature review were to comprehensively assess evidence regarding the performance characteristics of the MDA criteria and their utility as a measure of disease activity in PsA. Specifically, this review focused on summarising evidence of the validity of the MDA criteria, and the ability of the MDA criteria to detect between-groups and within-patient differences. The focus of this review was on MDA but when available, VLDA was reported.

\section{METHODS}

\section{Search methodology}

A targeted literature review was conducted to identify the existing evidence for the measurement properties of the MDA. Publications were identified using MEDLINE with PubMed Interface and Embase databases and there were no language or time frame restrictions for the literature search. The search terms used from controlled vocabularies MeSH were: 'minimal disease activity, minimal disease activity index, minimal disease activity measure, psoriatic arthritis, psoriatic arthropathy, surveys and 
Table 2 Relationship between MDA status and measures of structural damage

\begin{tabular}{|c|c|c|c|c|c|c|}
\hline Author (year) & Study description & $\begin{array}{l}\text { Definition } \\
\text { joint damage } \\
\text { progression }\end{array}$ & $\begin{array}{l}\text { Analysis } \\
\text { population/ } \\
\text { subgroups }\end{array}$ & Time point & Subgroup & Measure \\
\hline \multicolumn{6}{|c|}{ Cross-sectional studies } & $\begin{array}{l}\text { Presence of hand } \\
\text { erosions }\end{array}$ \\
\hline \multirow{3}{*}{$\begin{array}{l}\text { Queiro et al } \\
(2017)^{25}\end{array}$} & \multirow{3}{*}{$\begin{array}{l}\text { Cross-sectional } \\
\text { observational study }\end{array}$} & \multirow{3}{*}{$\begin{array}{l}\text { Presence of } \\
\text { hand erosions } \\
\text { by radiographic } \\
\text { evidence }\end{array}$} & \multirow[t]{3}{*}{-} & \multirow[t]{3}{*}{-} & MDA $(n=133)$ & $30.8 \%$ \\
\hline & & & & & $\begin{array}{l}\text { Non-MDA } \\
(n=144)\end{array}$ & $44.7 \%$ \\
\hline & & & & & $P$ value & $<0.05$ \\
\hline
\end{tabular}

Percentage of patients with no progression of joint

Longitudinal studies

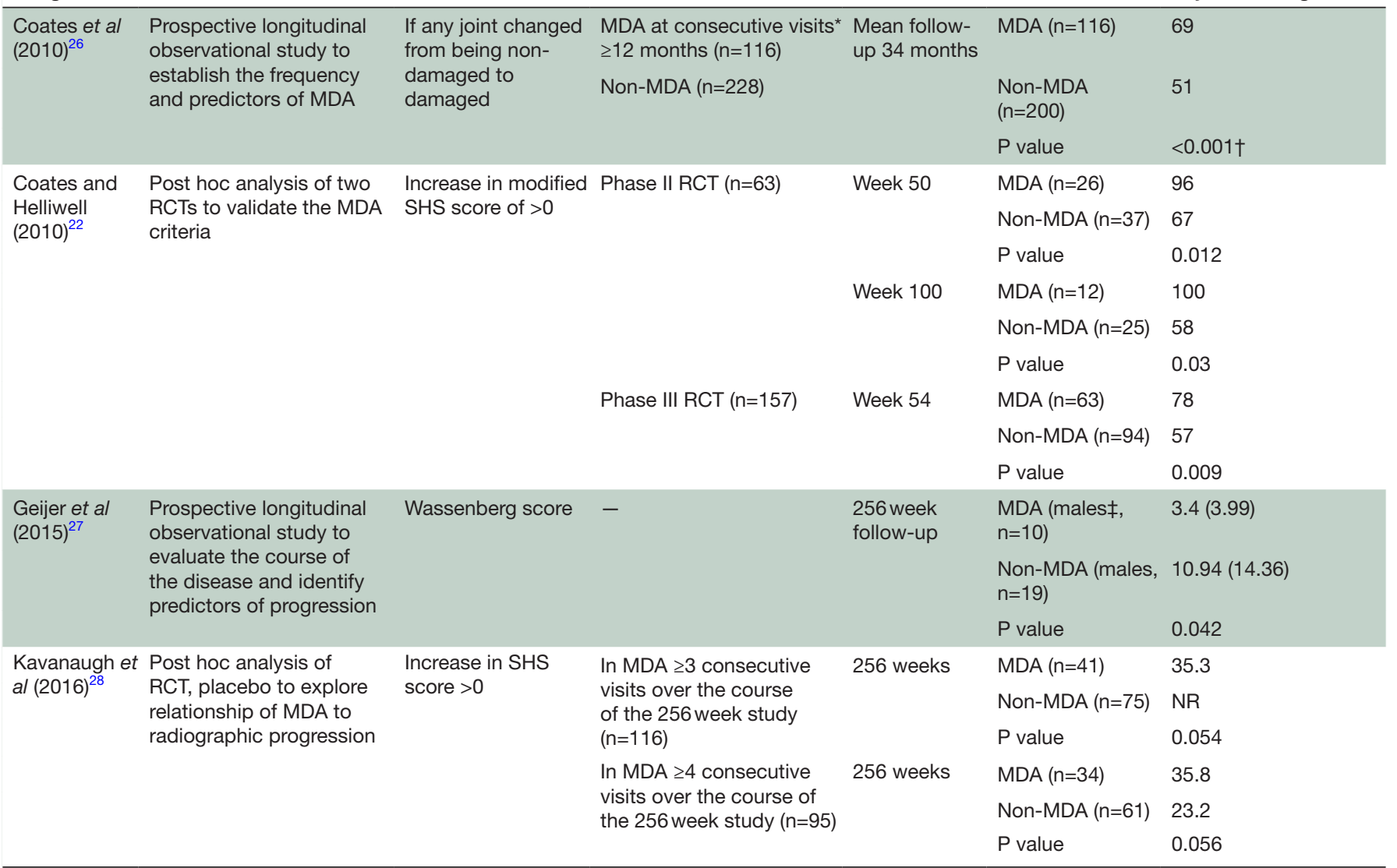

*Patients evaluated every 6-12 months.

†P value represents comparison of mean change in joint damage over the study period in MDA versus non-MDA.

¥Mean scores not reported for females; however, it was noted that the statistical comparison of joint damage for MDA versus non-MDA was not significant.

MDA, minimal disease activity; Non-MDA, patients not achieving MDA; NR, not reported; RCT, randomised controlled trial; SHS, Sharp/van der Heijde Score.

questionnaires, questionnaires and rating scales, outcome assessment, minimal important change,' and combinations thereof. In addition, pertinent articles provided by the investigators were evaluated for selection, including abstracts from conference proceedings from the annual ACR meetings and EULAR meetings. The same selection criteria were applied to articles identified in literature databases and to conference abstracts.

Publications were identified in two separate literature searches. The first was conducted in February 2016; this search was updated in October 2017.

\section{Study selection and data extraction}

After an initial screen of title and abstract, potentially relevant full-text publications were retrieved for further review. Articles were included if they provided evidence regarding the development or measurement properties of the MDA. Publications were excluded if they met any of the following criteria: reported only the rationale for developing the MDA; examined the relationship between baseline variables associated with achievement of MDA but did not inform measurement properties; clinical effectiveness studies with no comparator group; and 


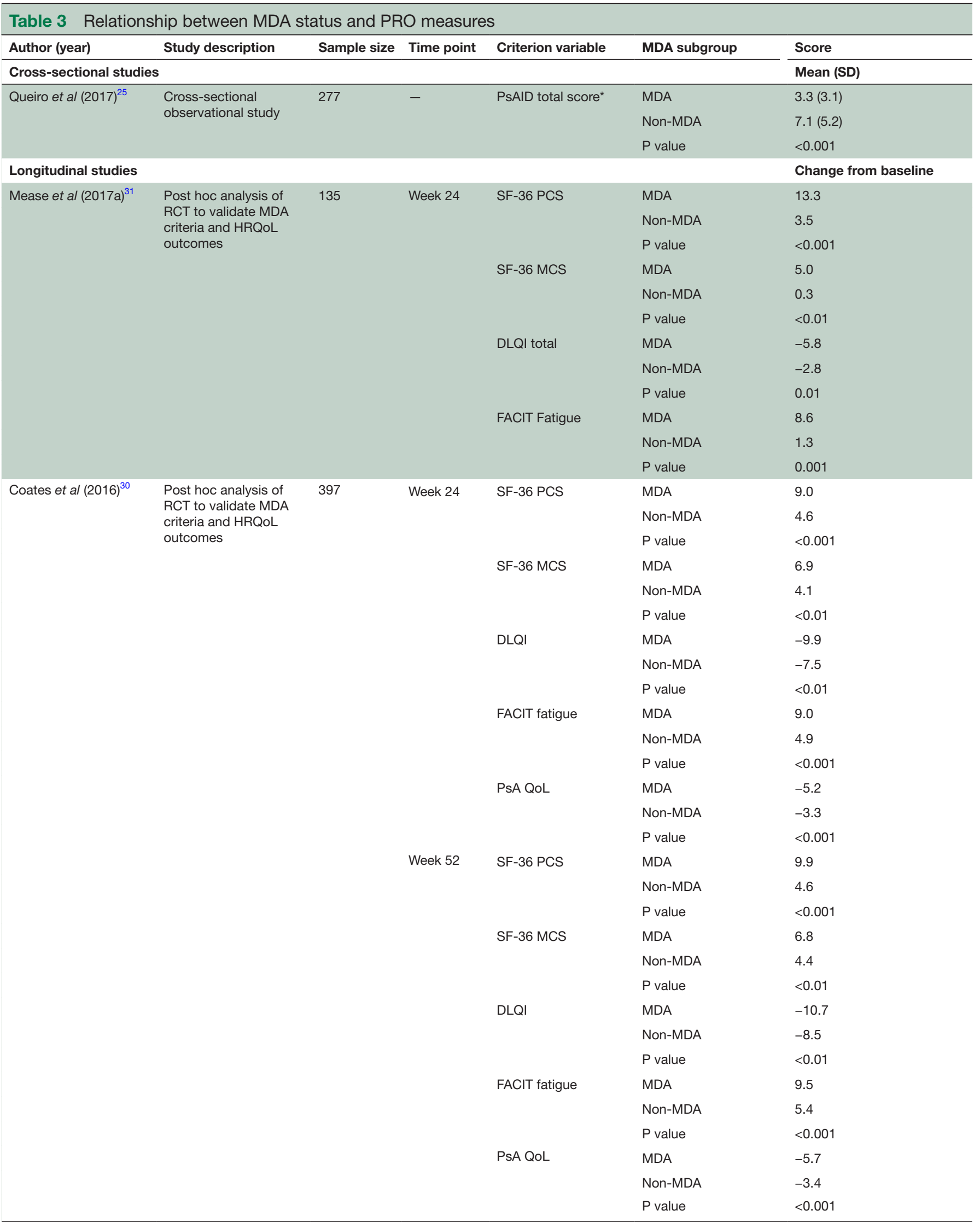

*PsAID total score ranges from 0 (best health status) to 10 (worst health status).

DLQI, Dermatology Life Quality Index; FACIT, Functional Assessment of Chronic Illness Therapy; HRQoL, health-related quality of life;MCS, Mental Component Score; MDA, minimal disease activity; Non-MDA, patients not achieving MDA;PCS, Physical Component Score; PROs, patient-reported outcomes; PsAID, Psoriatic Arthritis Impact of Disease; PsA QoL, psoriatic arthritis quality of life; RCT, randomised controlled trial; SF-36, Short Form 36 Health Survey. 
Table 4 Kappa's agreement between MDA and alternate disease activity criteria

\begin{tabular}{|c|c|c|c|c|c|}
\hline Author (year) & Study description & $\begin{array}{l}\text { Sample } \\
\text { size }\end{array}$ & Time point & Criterion & $\kappa$ \\
\hline \multicolumn{6}{|c|}{ Measures of disease activity } \\
\hline \multirow{3}{*}{$\begin{array}{l}\text { Coates and Helliwell } \\
(2016)^{32}\end{array}$} & \multirow{3}{*}{$\begin{array}{l}\text { Prospective longitudinal observational study of } \\
\text { GRACE dataset collected from } 32 \text { countries to } \\
\text { explore the relationship between MDA and low } \\
\text { disease activity cutoffs }\end{array}$} & \multirow[t]{3}{*}{503} & \multirow[t]{3}{*}{ Week 24} & PASDAS & 0.73 \\
\hline & & & & CPDAI-4 & 0.75 \\
\hline & & & & CPDAI-3 & 0.75 \\
\hline \multirow[t]{3}{*}{ Rahman et al $(2017)^{33}$} & \multirow[t]{3}{*}{ Prospective longitudinal observational study } & \multirow[t]{3}{*}{223} & \multirow[t]{3}{*}{12 months } & DAS28 (<2.6) & 0.65 \\
\hline & & & & DAS28 deep remission (1.98) & 0.60 \\
\hline & & & & DAPSA remission $(\leq 4)$ & 0.65 \\
\hline \multirow[t]{3}{*}{ Lubrano et al (2015) } & \multirow{3}{*}{$\begin{array}{l}\text { Prospective longitudinal observational study to } \\
\text { compare PtGA with MDA and other outcome } \\
\text { measures. }\end{array}$} & \multirow[t]{3}{*}{124} & 4 months & PtGA & 0.73 \\
\hline & & & 8 months & PtGA & 0.72 \\
\hline & & & 12 months & PtGA & 0.73 \\
\hline \multicolumn{6}{|l|}{ Categorical measures } \\
\hline \multirow{2}{*}{$\begin{array}{l}\text { Coates and Helliwell } \\
(2016)^{32}\end{array}$} & \multirow[t]{2}{*}{ Described above } & \multirow[t]{2}{*}{503} & \multirow[t]{2}{*}{ Week 24} & MDA-joints* & 0.86 \\
\hline & & & & MDA-phys $†$ & 0.48 \\
\hline
\end{tabular}

*BSA, and not the PASI, was the cut-off used for the skin domain.

TMDA as judged by the treating physician=do you think this patient is in an MDA state? (yes/no).

BSA, body surface area; CPDAI, Composite Psoriatic Disease Activity Index; DAPSA, Disease Activity in Psoriatic Arthritis; DAS28, Disease Activity Score using 28 joints; GRACE,

Group for Assessment of Psoriasis and Psoriatic Arthritis (GRAPPA) Composite Disease Exercise; MDA, minimal disease activity; PASDAS, Psoriatic Arthritis Disease Activity Score;

PASI, Psoriasis Area and Severity Index; PtGA, patient global assessment.

conference abstracts except those reporting results of phase III RCTs.

All studies were reviewed by an independent reviewer and the following data were extracted: author and year of publication; study characteristics, including study design and type (including but not limited to RCTs and post hoc analysis of RCTs; LOS and post hoc analyses of LOS; study years; sample size; study population characteristics; experimental treatment and findings related to the measurement properties of the MDA.

To evaluate the validity of the MDA, reported clinical endpoints were assessed and descriptive data and statistical comparisons were extracted for patients in MDA versus non-MDA for the following variables, where available:

1. $\mathrm{C}$ reactive protein $(\mathrm{CRP})$ - patients in MDA were expected to have lower CRP levels, indicative of overall lower levels of inflammation.

2. Structural damage-patients in MDA were expected to have less evidence of joint damage by radiographs and/or clinical report.

3. Patient-reported outcomes (PROs) - patients in MDA were expected to report better HRQoL, physical and mental function, and lower levels of fatigue relative to patients not in MDA.

To further evaluate the validity of the MDA, Kappa's agreement statistics were summarised between MDA and alternate measures of disease activity, where available. The kappa values associated with the level of agreement are as follows: none $(\kappa=0-0.2)$; minimal $(\kappa=0.21-0.39)$; weak $(\kappa=0.40-0.59)$; moderate $(\kappa=0.60-0.79)$; strong $(\kappa=0.80-0.90)$ and almost perfect $(\kappa>0.90) .{ }^{24}$

To determine the ability of the MDA to detect changes in clinical studies, descriptive data and statistical comparisons were extracted for treatment and comparator groups in RCTs and LOS. Study drugs with known efficacy were assessed for the percentage of patients taking the active treatment relative to the comparator arm in achieving MDA; a greater percentage receiving active treatment were expected to achieve MDA compared with those receiving placebo.

\section{RESULTS}

\section{Search results and study characteristics}

The combined literature reviews identified 20 relevant publications that provided information on the measurement properties of the MDA and these were selected for data extraction. One publication was a conference abstract presenting results of a phase III trial and the remainder of the publications were journal articles. Of these 20 publications, nine articles reported results from observational studies and the remaining reported results from RCTs. All publications that met eligibility criteria are summarised in online supplementary table S1.

\section{Validity}

\section{MDA status and CRP}

Two studies assessed the relationship between MDA and CRP, a marker of systemic inflammation (table 1).

Coates and Helliwell evaluated the ability of the MDA to differentiate among patients based on CRP and found an association between CRP levels and achievement of MDA. ${ }^{22}$ In this analysis, CRP levels were significantly lower in patients who achieved MDA than in those who did not $(\mathrm{p}=0.019)$. Results of a cross-sectional observational study among Spanish PsA patients published by Queiro et al were consistent with the above findings. ${ }^{25}$ Queiro et al reported that CRP scores were significantly lower in patients in MDA than in those who were not $(\mathrm{p}<0.05)$. 
Table 5 Ability to detect change in RCTs

\begin{tabular}{|c|c|c|c|c|c|c|}
\hline \multirow[b]{2}{*}{ Author (year) } & \multirow[b]{2}{*}{ Study description } & \multicolumn{2}{|l|}{ Sample size } & \multirow[b]{2}{*}{ Time point } & \multirow[b]{2}{*}{ Primary comparison } & \multirow{2}{*}{$\begin{array}{l}\text { Percentage } \\
\text { of patients } \\
\text { achieving MDA }\end{array}$} \\
\hline & & Total & PsA only & & & \\
\hline \multirow{6}{*}{$\begin{array}{l}\text { Coates and Helliwell } \\
(2010)^{22}\end{array}$} & \multirow{6}{*}{$\begin{array}{l}\text { Post hoc analysis of two RCTs } \\
\text { to validate the MDA criteria }\end{array}$} & \multirow{3}{*}{ Phase $2=63$} & \multirow[t]{3}{*}{63} & \multirow[t]{3}{*}{ Week 16} & Infliximab & 48 \\
\hline & & & & & Placebo & 3 \\
\hline & & & & & $P$ value & $<0.0001$ \\
\hline & & \multirow[t]{3}{*}{ Phase $3=157$} & \multirow[t]{3}{*}{157} & \multirow[t]{3}{*}{ Week 24} & Infliximab & 52 \\
\hline & & & & & Placebo* & 21 \\
\hline & & & & & $P$ value & $<0.001$ \\
\hline \multirow[t]{5}{*}{ Coates et al (2016) 30} & \multirow{5}{*}{$\begin{array}{l}\text { Post hoc analysis of phase } \\
\text { III RCT }\end{array}$} & \multirow[t]{5}{*}{397} & \multirow[t]{5}{*}{397} & \multirow[t]{3}{*}{ Week 16} & Secukinumab $150 \mathrm{mg}$ & 23 \\
\hline & & & & & Secukinumab $300 \mathrm{mg}$ & 28 \\
\hline & & & & & Placebo & 10 \\
\hline & & & & \multirow[t]{2}{*}{ Week 52} & Secukinumab $150 \mathrm{mg}$ & 33 \\
\hline & & & & & Secukinumab $300 \mathrm{mg}$ & 35 \\
\hline \multirow{9}{*}{$\begin{array}{l}\text { Gladman et al } \\
(2017)^{41}\end{array}$} & Phase III RCT, placebo & 394 & 394 & Week 12 & Tofacitinib $5 \mathrm{mg}$ & 22.9 \\
\hline & & & & & Tofacitinib $10 \mathrm{mg}$ & 21.2 \\
\hline & & & & & Placebo & 14.5 \\
\hline & & & & & $P$ value & NR \\
\hline & & & & Week 28 & Tofacitinib $5 \mathrm{mg}$ & 23.7 \\
\hline & & & & & Tofacitinib $10 \mathrm{mg}$ & 23.5 \\
\hline & & & & & Placebo/tofacitinib $5 \mathrm{mg}$ & 18.2 \\
\hline & & & & & Placebo/tofacitinib $10 \mathrm{mg}$ & 29.2 \\
\hline & & & & & $P$ value & NR \\
\hline Kavanaugh et al & Post hoc analysis of & 395 & 395 & Week 14 & Golimumab & 23.5 \\
\hline & $\mathrm{RCT}$, placebo to explore & & & & Placebo & 1 \\
\hline & radiographic progression & & & & $P$ value & $<0.0001$ \\
\hline & & & & Week 24 & Golimumab & 28.1 \\
\hline & & & & & Placebo & 7.7 \\
\hline & & & & & $P$ value & $<0.0001$ \\
\hline & & & & Week 52 & Golimumab & 42.4 \\
\hline & & & & & Placebo & 30.2 \\
\hline & & & & & $P$ value & $<0.0001$ \\
\hline & & & & $\geq 5$ consecutive time & Golimumab & 24.9 \\
\hline & & & & points & Placebo & 12.3 \\
\hline & & & & & $P$ value & 0.007 \\
\hline & & & & $\geq 6$ consecutive time & Golimumab & 16.6 \\
\hline & & & & points & Placebo & 2.8 \\
\hline & & & & & $P$ value & 0.000 \\
\hline & & & & $\geq 7$ consecutive time & Golimumab & 11.4 \\
\hline & & & & & Placebo & 0 \\
\hline & & & & & $P$ value & 0.000 \\
\hline Mease et al $(2017)^{31}$ & Phase III RCT & 313 & 136 & Week 24 & Adalimumab & 36.4 \\
\hline & $\begin{array}{l}\text { (week 24-active treatment } \\
\text { end of study; weeks } 48-144-\end{array}$ & & & & Placebo & 5.8 \\
\hline & open-label extension) & & & & $P$ value & $<0.001$ \\
\hline & & & & Week 48 & Adalimumab & 43.1 \\
\hline & & & & (open-label extension) & Adalimumab naïve & 32.2 \\
\hline & & & & Week 96 & Adalimumab & 37.9 \\
\hline & & & & (open-label extension) & Adalimumab naïve & 27.1 \\
\hline & & & & Week 144 & Adalimumab & 34.5 \\
\hline & & & & (open-label extension) & Adalimumab naïve & 22.0 \\
\hline
\end{tabular}


Table 5 Continued

\begin{tabular}{|c|c|c|c|c|c|c|}
\hline \multirow[b]{2}{*}{ Author (year) } & \multirow[b]{2}{*}{ Study description } & \multicolumn{2}{|c|}{ Sample size } & \multirow[b]{2}{*}{ Time point } & \multirow[b]{2}{*}{ Primary comparison } & \multirow{2}{*}{$\begin{array}{l}\text { Percentage } \\
\text { of patients } \\
\text { achieving MDA }\end{array}$} \\
\hline & & Total & PsA only & & & \\
\hline \multirow[t]{3}{*}{ Mease et al $(2014)^{42}$} & \multirow{3}{*}{$\begin{array}{l}\text { Post hoc analysis of RCT data } \\
\text { to explore relationship with } \\
\text { MDA }\end{array}$} & \multirow[t]{3}{*}{409} & \multirow[t]{3}{*}{409} & \multirow[t]{3}{*}{ Week 24} & $\begin{array}{l}\text { Certolizumab pegol } \\
\text { (200mg and } 400 \mathrm{mg} \text { ) }\end{array}$ & $33.3 ; 34.1$ \\
\hline & & & & & Placebo & 5.9 \\
\hline & & & & & $P$ value & $<0.001$ \\
\hline \multirow[t]{2}{*}{ Mease et al $(2015)^{43}$} & \multirow[t]{2}{*}{$\begin{array}{l}\text { Post hoc analysis of RCT data } \\
\text { to explore relationship with } \\
\text { MDA }\end{array}$} & \multirow[t]{2}{*}{409} & \multirow[t]{2}{*}{409} & Week 48 (imputation) & $\begin{array}{l}\text { Certolizumab pegol } \\
\text { (combined patients } \\
\text { randomised to active treatment } \\
\text { at baseline) }\end{array}$ & 38.8 \\
\hline & & & & Week 96 (imputation) & $\begin{array}{l}\text { Certolizumab pegol } \\
\text { (combined patients } \\
\text { randomised to active treatment } \\
\text { at baseline) }\end{array}$ & 41.0 \\
\hline \multirow[t]{6}{*}{ Mease et al $(2017)^{19}$} & \multirow{6}{*}{$\begin{array}{l}\text { Post hoc analysis of RCT, } \\
\text { placebo to investigate } \\
\text { achievement of MDA }\end{array}$} & \multirow[t]{6}{*}{424} & \multirow[t]{6}{*}{424} & \multirow[t]{3}{*}{ Week 24} & Abatacept & 11.7 \\
\hline & & & & & Placebo & 8.1 \\
\hline & & & & & $P$ value & 0.205 \\
\hline & & & & \multirow{3}{*}{$\begin{array}{l}\text { Week } 52 \\
\text { (open-label extension) }\end{array}$} & Abatacept & 17.4 \\
\hline & & & & & Placebo/abatacept & 18.5 \\
\hline & & & & & $P$ value & NR \\
\hline \multirow[t]{8}{*}{ Mease et al $(2017)^{44}$} & \multirow[t]{8}{*}{$\begin{array}{l}\text { Phase III RCT to investigate } \\
\text { achievement of MDA }\end{array}$} & \multirow{8}{*}{422} & \multirow[t]{8}{*}{422} & \multirow[t]{4}{*}{ Week 12} & $\begin{array}{l}\text { Tofacitinib } \\
\text { (5 mg and } 10 \mathrm{mg})\end{array}$ & $26.0 ; 26.0$ \\
\hline & & & & & Adalimumab & 25.0 \\
\hline & & & & & Placebo (pooled) & 7.0 \\
\hline & & & & & $P$ value & NR \\
\hline & & & & Week 52 & $\begin{array}{l}\text { Tofacitinib } \\
\text { (5 mg and } 10 \mathrm{mg})\end{array}$ & $37.0 ; 43.0$ \\
\hline & & & & & Adalimumab & 40.0 \\
\hline & & & & & $\begin{array}{l}\text { Placebo/tofacitinib } \\
\text { (5 mg and } 10 \mathrm{mg})\end{array}$ & $31.0 ; 34.0$ \\
\hline & & & & & $P$ value & NR \\
\hline \multirow[t]{3}{*}{ Nash et al $(2017)^{45}$} & \multirow{3}{*}{$\begin{array}{l}\text { Post hoc analysis of RCT, } \\
\text { placebo to investigate } \\
\text { achievement of MDA }\end{array}$} & \multirow[t]{3}{*}{363} & \multirow[t]{3}{*}{363} & \multirow[t]{3}{*}{ Week 24} & $\begin{array}{l}\text { Ixekizumab } \\
\text { (2 weeks; } 4 \text { weeks) }\end{array}$ & $24.0 ; 28.0$ \\
\hline & & & & & Placebo & 3 \\
\hline & & & & & $P$ value & $<0.0001$ \\
\hline
\end{tabular}

${ }^{*}$ Forty-seven patients in the placebo group entered the early escape arm at week 16 and received infliximab.

MDA, minimal disease activity; NR, not reported; PsA, psoriatic arthritis; RCT, randomised controlled trial.

\section{MDA status and measures of structural damage}

Queiro et al reported the relationship between MDA and presence of radiographic erosions in the hands and feet in a cross-sectional study (table 2$).{ }^{25}$

Patients in MDA were less likely to have evidence of hand erosions compared with those who were not $(p<0.05)$; however, there were no significant differences among patients when evaluating presence of erosions in the feet.

Four longitudinal studies reported the progression of structural damage over time in patients achieving MDA and in those who did not (table 2). ${ }^{22} 26-28$ Across these studies, patients in MDA had lower rates of structural damage progression; these differences were statistically significant in three of four studies. In a post hoc analysis of phase II and phase III RCTs, Coates and Helliwell reported that patients in MDA were less likely to exhibit structural damage progression. ${ }^{22}$ In the phase II RCT, patients achieving MDA were significantly less likely to have increases $>0$ in the modified Sharp/van der Heijde Scores (SHS) at week $50 \quad(p=0.012)$ and week $100(\mathrm{p}=0.03)$ compared with patients not in MDA. In the phase III trial, patients in MDA at week 54 were also less likely to have evidence of structural damage progression $(\mathrm{p}=0.009)$. Kavanaugh et al conducted a post hoc analysis of a phase III RCT that reported the relationship between achievement of MDA over consecutive study visits ( $\geq 3$ visits and $\geq 4$ visits) and increases in SHS $>0$ over the 256 -week treatment period. ${ }^{28}$ Results for both subgroups ( $\geq 3$ and $\geq 4$ ) were in the anticipated direction; however, they were not statistically significant $(p=0.054$ and $p=0.056$, respectively $)$. Coates et $a l$ assessed the rate of structural damage progression over a 5-year prospective LOS among patients in MDA and those who were not. ${ }^{26}$ The average follow-up was 34 months and patients in MDA were significantly less likely to have structural damage progression $(\mathrm{p}<0.001)$. The rate of structural damage progression by the 
Table 6 Ability to detect change in prospective LOS

\begin{tabular}{|c|c|c|c|c|c|}
\hline Author (year) & Study description & $\begin{array}{l}\text { Sample } \\
\text { size }\end{array}$ & Treatment & Time point & $\begin{array}{l}\text { Percentage } \\
\text { of patients } \\
\text { achieving MDA }\end{array}$ \\
\hline \multirow{4}{*}{$\begin{array}{l}\text { Rahman et al } \\
(2017)^{33}\end{array}$} & \multirow{4}{*}{$\begin{array}{l}\text { Biological treatment registry to } \\
\text { examine MDA rate over time }\end{array}$} & \multirow[t]{4}{*}{233} & \multirow{4}{*}{$\begin{array}{l}\text { Infliximab, golimumab, } \\
\text { ustekinumab }\end{array}$} & Baseline & 11.7 \\
\hline & & & & Week 26 & $43.5^{*}$ \\
\hline & & & & Week 52 & $44.8^{\star}$ \\
\hline & & & & $P$ value & $<0.001$ \\
\hline \multirow{4}{*}{$\begin{array}{l}\text { Perrotta et al } \\
(2016)^{36}\end{array}$} & \multirow{4}{*}{$\begin{array}{l}\text { Prospective longitudinal study } \\
\text { to examine MDA status with the } \\
\text { indices of disease activity and to } \\
\text { identify predictors for MDA }\end{array}$} & \multirow[t]{4}{*}{75} & \multirow{4}{*}{$\begin{array}{l}\text { Adalimumab, } \\
\text { etanercept, } \\
\text { golimumab }\end{array}$} & Baseline & 0 \\
\hline & & & & 4 months & 22.6 \\
\hline & & & & 8 months & 56.0 \\
\hline & & & & 12 months & $61.3 \dagger$ \\
\hline
\end{tabular}

${ }^{*} \mathrm{P}<0.001$.

†Article reports the percentage of patients achieving MDA status at 12 months was significantly different from baseline but does not report $\mathrm{p}$ value.

LOS, longitudinal observational studies; MDA, minimal disease activity.

Wassenberg score over a 256-week follow-up period in a prospective LOS has been reported by Geijer et al for a cohort of PsA patients in Sweden and was found to be significantly lower among patients in MDA $(\mathrm{p}=0.042){ }^{27}$

\section{MDA status and PROs}

Three studies examined the relationship between MDA status and PROs and are summarised in table 3.

The relationship between MDA status and physical and psychological function measured by the PsA Impact of Disease Questionnaire (PsAID) was evaluated by Queiro and colleagues in an observational, cross-sectional study. ${ }^{25}$ The PsAID measures the physical and psychological impact of disease on patients' lives. ${ }^{29}$ Results indicated that patients in MDA reported significantly lower impacts of disease than patients who were not in MDA across all domains and total PsAID scores $(p<0.001){ }^{25}$ Eighty-eight $(66.7 \%)$ MDA patients reported a PsAID score $<4$ compared with $34(37.4 \%)$ non-MDA patients $(\mathrm{p}<0.0001)$.

Two studies reported the relationship between changes over time in PROs and MDA. In both, patients in MDA reported significantly more improvements across all PROs assessing HRQOL and fatigue: Short Form 36 Health Survey, Dermatology Life Quality Index (DLQI), Functional Assessment of Chronic Illness Therapy-Fatigue, and PsA quality of life. ${ }^{30}$ Additional data from these studies are summarised in table 3 .

\section{AGREEMENT BETWEEN MDA AND ALTERNATIVE MEASURES OF DISEASE ACTIVITY}

Several publications evaluated the relationship between MDA and other overall disease activity indicators (such as the PASDAS, CPDAI, Disease Activity Score (DAS), DAPSA and PtGA) by calculating Kappa's ( $\kappa)$ coefficients (table 4).

Coates and Helliwell reported moderate agreement $(\kappa=0.73-0.75)$ with three alternative definitions of treatment responses: PASDAS, CPDAI- 4 and CPDAI- $3 .{ }^{32}$ Agreement was also strong for MDA joints $(\kappa=0.86)$ but weak for MDA-phys $(\kappa=0.48)$. The relationship between MDA and disease activity reported by the patient (measured as a patient-reported overall indicator of disease activity) was also evaluated. The $\kappa$ coefficient between MDA and patients' rating of whether they were in a minimal disease state was 0.30 .

Rahman et alreported a moderate $\kappa$ agreement between achievement of MDA and three additional disease activity measures, including DAS using 28 joints (DAS28, <2.6), DAS28 deep remission (DAS28 $<1.98$ ) and DAPSA remission $(\leq 4) .{ }^{33}$ Lubrano et al reported moderate agreement between MDA and a single item of the MDA, PtGA $(\kappa=0.72-0.73) .{ }^{34}$ As part of the same LOS, Lubrano et al then evaluated the sensitivity and specificity in differentiating patients rated by their physician as being in MDA $(<10 \mathrm{~mm}$ on a $100 \mathrm{~mm}$ VAS $)$ versus a higher disease state $(\geq 10)$; sensitivity was $0.90(0.74-0.98)$ and specificity 0.69 $(0.57-0.79){ }^{35}$

\section{Ability to detect change}

Ten RCTs that provide evidence on the between-patient treatment effects of the MDA were identified (table 5) and indicated that those who received treatment with a targeted immunomodulator were significantly more likely to achieve MDA than those who received placebo.

Two prospective LOS provide evidence on the within-patient treatment effects (table 6). In these studies, over 1year of treatment with a disease-modifying antirheumatic drug resulted in an increasing proportion of patients achieving MDA. ${ }^{33} 36$

\section{Very low disease activity}

One study reported both MDA and VLDA from a post hoc analysis of a 24-week RCT that compared adalimumab to placebo. Mease et al reported that of 66 patients receiving adalimumab, $24(36.4 \%)$ achieved MDA and 10 (15.4\%) 
VLDA. In contrast, of 69 patients in the placebo group, only four $(5.7 \%)$ and zero $(0 \%)$, respectively, achieved MDA and VLDA. ${ }^{31}$

\section{DISCUSSION}

This targeted literature review assessed the current evidence of the performance characteristics of the MDA criteria and their utility as a measure of disease activity in PsA. The validity and relevance of the MDA as a measure of disease activity was strongly supported based on the strength and consistent association between MDA status and each of these domains.

Across studies, MDA responses were in the anticipated direction of other disease indicators, such as CRP, structural damage progression, patient-reported HRQoL, pain and fatigue and global assessments of disease activity. The consistency reported in the literature provides strong evidence that MDA is a valid indicator of disease activity in PsA.

MDA is frequently reported in RCTs that examine the efficacy of treatments for PsA. Across all RCTs included in this literature review, a greater proportion of patients assigned active treatment achieved MDA versus placebo/ control groups. A growing body of evidence also supports the ability of the MDA criteria to detect within-patient changes over time, providing further support for its use in LOS and RCTs.

Recent T2T recommendations have highlighted the aspiration for remission or VLDA, but for many patients, low disease activity or MDA may be an appropriate treatment target. ${ }^{13}$ The MDA criteria have been recommended by both the T2T international task force ${ }^{13}$ and the GRAPPA/OMERACT group to assess treatment target goals. ${ }^{37}$ While MDA does not measure disease activity, it is a feasible target of treatment assessing multiple domains of the disease. The MDA criteria can be used in all patients with PsA regardless of their disease pattern, whereas other measures do not reflect disease activity across all subgroups of PsA. It gives a target that is appropriate for both polyarticular and oligoarticular patients. In some other measures (eg, ACR response and DAPSA) of disease activity the focus is primarily on articular inflammation, ${ }^{13}$ which may not reflect the full range of disease activity in some PsA patients. PASDAS is another disease activity measure that covers multiple domains, but it does not include skin and is complex to use in clinical practice at present.

Measures like MDA that generally focuses on multiple domains of the disease can evade inclusion of patients having an active domain, which may otherwise be categorised as cohort with remission or low disease activity. van Mens et al reported that prevalence of skin disease was higher in patients with PsA who had DAPSA remission compared with other measures. Given that DAPSA is an unidimensional measure, it particularly focuses only on peripheral joint disease. Hence, it does not address important manifestations of PsA, where MDA, a multidimensional measure, addresses all of them. ${ }^{38}$ In a recently published study, Coates et al concluded that in comparison with DAPSA, definitions of VLDA and MDA are more stringent in evaluating PsA. ${ }^{39}$

The MDA criteria offer a targeted and easy to interpret disease assessment, and have been incorporated into both clinical practice and trial settings. ${ }^{38} \mathrm{MDA}$ is based on commonly performed clinical examinations, with some additional, easy to administer PROs (ie, PtGA, pain VAS and HAQ) and skin evaluations (ie, PASI or BSA), and determining MDA requires minimal training and time for the required assessments. PRO measures are increasingly being incorporated into clinical practice settings, which will further enable assessment of MDA. ${ }^{40}$

There are several limitations to this targeted literature review that warrant consideration when interpreting the results presented in this manuscript. This review sought to qualitatively characterise information on the measurement properties of the MDA. Although a thorough search strategy was employed to capture all pertinent publications, the potential exists that not all relevant publications were identified. Further investigation into this is needed to evaluate stability of the score among patients with stable disease activity. Furthermore, each of the studies included in this review used different methodological approaches to study design (cross-sectional vs longitudinal), population analysed, study duration and endpoints evaluated, thereby limiting the ability to collectively summarise findings.

This literature review provides a detailed evaluation of the measurement properties of the MDA and shows strong evidence for the validity of the MDA as a measure of PsA disease activity and its sensitivity to detect changes with treatment. Substantial data support its use as a practical, comprehensive and clinically meaningful endpoint for clinicians to assess the impact of specific treatment interventions on PsA disease activity.

\section{Author affiliations}

${ }^{1}$ Nuffield Department of Orthopaedics, Rheumatology and Musculoskeletal Sciences, University of Oxford, Oxford, UK

${ }^{2}$ Immunology/Rheumatology, Stanford University, Stanford, California, USA

${ }^{3}$ Biopharmaceutical Consultant, Portola Valley, California, USA

${ }^{4}$ Boehringer-Ingelheim, Ridgefield, Connecticut, USA

${ }^{5}$ Evidera Inc, Bethesda, Maryland, USA

${ }^{6}$ Amgen, Thousand Oaks, California, USA

${ }^{7}$ Pharmaceutical Product Development, San Diego, California, USA

${ }^{8}$ Amgen Inc, Thousand Oaks, California, USA

${ }^{9}$ Medicine/Rheumatology, Krembil Research Institute, Toronto, Ontario, Canada

${ }^{10}$ School of Medicine, Swedish Medical Center and University of Washington,

Seattle, Washington, USA

Acknowledgements The authors would like to thank Kendra Hughes, PharmD and Melanie Jardim, PhD (Evidera, Morrisville, NC) for medical writing and editorial support, which was funded by Amgen.

Contributors All authors listed meet the requirements for authorship and have read and approved this final version of the modified manuscript.

Funding This targeted literature review was funded by Amgen.

Disclaimer The views expressed are those of the author(s) and not necessarily those of the NHS, the NIHR, or the Department of Health. 
Competing interests LCC has received research funding and/or honoraria from AbbVie, Amgen, BMS, Celgene, Galapagos, Janssen, Lilly, MSD, Novartis, Pfizer, Prothena, Sun Pharma, and UCB. LCC is funded by a National Institute for Health Research Clinician Scientist award. The research was supported by the National Institute for Health Research (NIHR) Oxford Biomedical Research Centre (BRC). VS consults for Amgen, AbbVie, AstraZeneca, BMS, Boehringer Ingelheim, Celltrion, GSK, Janssen, Kezar, Lilly, Merck, Novartis, Pfizer, Samsung, Sandoz, Sanofi, and UCB. HW was an Evidera employee during study conduct and Evidera received research funding for the project from Amgen. HW is currently an employee of Boehringer Ingelheim. DR is employed by Evidera which received research support from Amgen for this project and received research support from Pfizer. DR owns stock in AbbVie, Pfizer, and Amgen. BS, AS and JBC are employees of Amgen and are Amgen stock owners. DG received grant support and/or consulting fees from AbbVie, Amgen, BMS, Celgene, Eli Lilly, Gilead, Galapagos, Janssen, Novartis, Pfizer and UCB. PJM has received research funding, consulting or speaker honoraria from AbbVie, Amgen, BMS, Celgene, Galapagos, Genentech, Janssen, Lilly, Merck, Novartis, Pfizer, Prothena, Sun Pharma and UCB.

Patient consent for publication Not required.

Provenance and peer review Not commissioned; externally peer reviewed.

Data availability statement All data relevant to the study are included in the article or uploaded as online supplementary information.

Open access This is an open access article distributed in accordance with the Creative Commons Attribution Non Commercial (CC BY-NC 4.0) license, which permits others to distribute, remix, adapt, build upon this work non-commercially, and license their derivative works on different terms, provided the original work is properly cited, appropriate credit is given, any changes made indicated, and the use is non-commercial. See: http://creativecommons.org/licenses/by-nc/4.0/.

\section{REFERENCES}

1. Coates LC, FitzGerald O, Helliwell PS, et al. Psoriasis, psoriatic arthritis, and rheumatoid arthritis: is all inflammation the same? Semin Arthritis Rheum 2016;46:291-304.

2. McArdle A, Pennington S, FitzGerald O. Clinical features of psoriatic arthritis: a comprehensive review of unmet clinical needs. Clin Rev Allergy Immunol 2018;55:271-94.

3. Ogdie A, Weiss P. The epidemiology of psoriatic arthritis. Rheum Dis Clin North Am 2015;41:545-68.

4. Mease PJ, Gladman DD, Papp KA, et al. Prevalence of rheumatologist-diagnosed psoriatic arthritis in patients with psoriasis in European/North American dermatology clinics. J Am Acad Dermatol 2013;69:729-35.

5. Coates LC, Kavanaugh A, Mease PJ, et al. Group for research and assessment of psoriasis and psoriatic arthritis 2015 treatment recommendations for psoriatic arthritis. Arthritis Rheumatol 2016;68:1060-71.

6. Bhole VM, Choi HK, Burns LC, et al. Differences in body mass index among individuals with PSA, psoriasis, RA and the general population. Rheumatology 2012;51:552-6.

7. Egeberg A, Khalid U, Gislason GH, et al. Association of psoriatic disease with uveitis: a Danish nationwide cohort study. JAMA Dermatol 2015;151.

8. Alamanos Y, Voulgari PV, Drosos AA. Incidence and prevalence of psoriatic arthritis: a systematic review. J Rheumatol 2008;35:1354-8.

9. Eder L, Haddad A, Rosen CF, et al. The incidence and risk factors for psoriatic arthritis in patients with psoriasis: a prospective cohort study. Arthritis Rheumatol 2016;68:915-23.

10. Ferguson EG, Coates LC. Optimisation of rheumatology indices: dactylitis and enthesitis in psoriatic arthritis. Clin Exp Rheumatol 2014;32(5 Suppl 85):S-113-7.

11. Gladman DD, Antoni $C$, Mease $P$, et al. Psoriatic arthritis: epidemiology, clinical features, course, and outcome. Ann Rheum Dis 2005;64(Suppl 2):ii14-17.

12. Gladman DD, Hing EN, Schentag CT, et al. Remission in psoriatic arthritis. J Rheumatol 2001;28:1045-8.

13. Smolen JS, Schöls M, Braun J, et al. Treating axial spondyloarthritis and peripheral spondyloarthritis, especially psoriatic arthritis, to target: 2017 update of recommendations by an international Task force. Ann Rheum Dis 2018;77:3-17.

14. Gossec L, Smolen JS, Ramiro S, et al. European League against rheumatism (EULAR) recommendations for the management of psoriatic arthritis with pharmacological therapies: 2015 update. Ann Rheum Dis 2016:75:499-510.

15. Orbai $A-M$, de Wit $M$, Mease PJ, et al. Updating the psoriatic arthritis (PSA) core domain set: a report from the PSA workshop at OMERACT 2016. J Rheumatol 2017;44:1522-8.
16. Felson DT, Anderson JJ, Boers M, et al. American College of rheumatology preliminary definition of improvement in rheumatoid arthritis. Arthritis Rheum 1995;38:727-35

17. Kavanaugh A, Krueger GG, Beutler A, et al. Infliximab maintains a high degree of clinical response in patients with active psoriatic arthritis through 1 year of treatment: results from the impact 2 trial. Ann Rheum Dis 2007:66:498-505.

18. Mease PJ, Mclnnes IB, Kirkham B, et al. Secukinumab inhibition of interleukin-17A in patients with psoriatic arthritis. N Engl J Med 2015;373:1329-39.

19. Mease PJ, Gottlieb AB, van der Heijde D, et al. Efficacy and safety of abatacept, a T-cell modulator, in a randomised, double-blind, placebo-controlled, phase III study in psoriatic arthritis. Ann Rheum Dis 2017;76:1550-8.

20. Gossec L, McGonagle D, Korotaeva T, et al. Minimal disease activity as a treatment target in psoriatic arthritis: a review of the literature. $J$ Rheumatol 2018;45:6-13.

21. Coates LC, Fransen J, Helliwell PS. Defining minimal disease activity in psoriatic arthritis: a proposed objective target for treatment. Ann Rheum Dis 2010:69:48-53.

22. Coates LC, Helliwell PS. Validation of minimal disease activity criteria for psoriatic arthritis using interventional trial data. Arthritis Care Res 2010;62:965-9.

23. Coates LC, Mease PJ, Gossec L, et al. Minimal disease activity among active psoriatic arthritis patients treated with secukinumab: 2-year results from a multicenter, randomized, double-blind, parallel-group, placebo-controlled phase III study. Arthritis Care Res 2018;70:1529-35.

24. McHugh ML. Interrater reliability: the kappa statistic. Biochem Med 2012;22.

25. Queiro R, Cañete JD, Montilla C, et al. Minimal disease activity and impact of disease in psoriatic arthritis: a Spanish cross-sectional multicenter study. Arthritis Res Ther 2017;19.

26. Coates LC, Cook R, Lee K-A, et al. Frequency, predictors, and prognosis of sustained minimal disease activity in an observational psoriatic arthritis cohort. Arthritis Care Res 2010;62:970-6.

27. Geijer M, Lindqvist U, Husmark T, et al. The Swedish early psoriatic arthritis registry 5-year followup: substantial radiographic progression mainly in men with high disease activity and development of dactylitis. J Rheumatol 2015;42:2110-7.

28. Kavanaugh $A$, van der Heijde $D$, Beutler $A$, et al. Radiographic progression of patients with psoriatic arthritis who achieve minimal disease activity in response to golimumab therapy: results through 5 years of a randomized, placebo-controlled study. Arthritis Care Res 2016;68:267-74.

29. Gossec L, de Wit M, Kiltz U, et al. A patient-derived and patientreported outcome measure for assessing psoriatic arthritis: elaboration and preliminary validation of the psoriatic arthritis impact of disease (PsAID) questionnaire, a 13-country EULAR initiative. Ann Rheum Dis 2014;73:1012-9.

30. Coates L, Mease PJ, Gossec L, et al. Patients with active psoriatic arthritis achieving minimal disease activity with secukinumab treatment demonstrate sustained improvement of function and quality of life [abstract]. Arthritis Rheumatol 2016;68.

31. Mease PJ, Kavanaugh A, Coates LC, et al. Prediction and benefits of minimal disease activity in patients with psoriatic arthritis and active skin disease in the ADEPT trial. RMD Open 2017;3:e000415

32. Coates LC, Helliwell PS. Defining low disease activity states in psoriatic arthritis using novel composite disease instruments. $J$ Rheumatol 2016;43:371-5.

33. Rahman $P$, Zummer M, Bessette L, et al. Real-World validation of the minimal disease activity index in psoriatic arthritis: an analysis from a prospective, observational, biological treatment registry. BMJ Open 2017; 7:e016619.

34. Lubrano E, Perrotta FM, Parsons WJ, et al. Patient's Global Assessment as an Outcome Measure for Psoriatic Arthritis in Clinical Practice: A Surrogate for Measuring Low Disease Activity? J Rheumatol 2015;42:2332-8.

35. Lubrano E, De Socio A, Perrotta FM. Comparison of composite indices tailored for psoriatic arthritis treated with csDMARD and bDMARD: a cross-sectional analysis of a longitudinal cohort. J Rheumatol 2017;44:1159-64.

36. Perrotta FM, Marchesoni A, Lubrano E. Minimal disease activity and remission in psoriatic arthritis patients treated with anti-TNF- $\alpha$ drugs. J Rheumatol 2016;43:350-5

37. Coates LC, FitzGerald O, Merola JF, et al. Group for research and assessment of psoriasis and psoriatic Arthritis/Outcome measures in rheumatology consensus-based recommendations and research agenda for use of composite measures and treatment targets in psoriatic arthritis. Arthritis Rheumatol 2018;70:345-55 
38. van Mens LJJ, van de Sande MGH, van Kuijk AWR, et al. Ideal target for psoriatic arthritis? comparison of remission and low disease activity states in a real-life cohort. Ann Rheum Dis 2018;77:251-7.

39. Coates LC, Gottlieb AB, Merola JF, et al. Comparison of different remission and low disease definitions in psoriatic arthritis and evaluation of their prognostic value. J Rheumatol 2019;46:160-5.

40. Holmes MM, Lewith G, Newell D, et al. The impact of patientreported outcome measures in clinical practice for pain: a systematic review. Qual Life Res 2017;26:245-57.

41. Gladman D, Rigby W, Azevedo VF, et al. Tofacitinib for psoriatic arthritis in patients with an inadequate response to TNF inhibitors. $N$ Engl J Med 2017;377:1525-36.

42. Mease PJ, Fleischmann R, Deodhar AA, et al. Effect of certolizumab pegol on signs and symptoms in patients with psoriatic arthritis: 24-week results of a phase 3 double-blind randomised placebo-controlled study (RAPID-PsA). Ann Rheum Dis 2014;73:48-55.

43. Mease P, Deodhar A, Fleischmann R, et al. Effect of certolizumab pegol over 96 weeks in patients with psoriatic arthritis with and without prior antitumour necrosis factor exposure. RMD Open 2015;1:e000119.

44. Mease P, Hall S, FitzGerald O, et al. Tofacitinib or adalimumab versus placebo for psoriatic arthritis. N Engl J Med 2017;377:1537-50.

45. Nash P, Kirkham B, Okada M, et al. Ixekizumab for the treatment of patients with active psoriatic arthritis and an inadequate response to tumour necrosis factor inhibitors: results from the 24-week randomised, double-blind, placebo-controlled period of the SPIRIT-P2 phase 3 trial. Lancet 2017;389:2317-27. 